Creative Commons User License: CC BY-NC-ND

Abstracted by: EBSCOhost, Electronic Journals Service (EJS),

Google Scholar, Journal Seek, Scientific Commons,

Food and Agricultural Organization (FAO), CABI and Scopus
Journal of Agricultural Extension

Vol. 26 (1) January, 2022

ISSN(e): 24086851; ISSN(Print); 1119944X

http://journal.aesonnigeria.org

http://www.ajol.info/index.php/jae

Email: editorinchief@aesonnigeria.org

\title{
Rural Women Farmers Participation in Planning and Implementation of Agricultural Practices in North Eastern Nigeria \\ https://dx.doi.org/10.4314/jae.v26i1.9
}

\section{Umar, Abdulmumini}

Department of Agriculture Technology, Faculty of Agriculture, Universiti Putra Malaysia (UPM), 43400 UPM Serdang, Selangor, Malaysia

Email: umwakill@gmail.com; Phone: +2348060643402

\section{Norsida, Man}

Department of Agriculture Technology, Faculty of Agriculture, Universiti Putra Malaysia (UPM), 43400 UPM Serdang, Selangor, Malaysia

Email: norsida@upm.edu.my Corresponding Author; Phone: +60-123993872

\section{Nur, Bahiah Mohd Haris}

Department of Agriculture Technology, Faculty of Agriculture, Universiti Putra Malaysia

(UPM), 43400 UPM Serdang, Selangor, Malaysia

Email: nurbahiah@upm.edu.my; Phone: +60-122859855

\section{Nitty, Hirawaty Kamarulzaman}

Department of Agribusiness and Bioresources Economy, Faculty of Agriculture, Universiti Putra Malaysia (UPM), 43400 UPM Serdang, Selangor, Malaysia

Email: nitty@upm.edu.my; Phone: +60-148213722

Abstract

The study investigated participation of women farmers in planning and implementation of agricultural practices in northeastern Nigeria. Multistage sampling procedure was used to select 378 respondents out of 6758 women farmers in the zone. Questionnaire was used to collect data from the sampled farmers. Mean and standard deviation were used for analyses of data. The study showed low level of women farmers participation in planning agricultural practices $(\bar{x}=2.27)$. Implementation of agricultural practices among women farmers had high-level participation $(\bar{x}=3.74)$. The need for extension programme that would ensure effective motivation by extension workers for meaningful participation of women farmers in planning and implementation of agricultural practices become necessary for increase productivity.

Keywords; Women farmers, motivation, agricultural practices

\section{Introduction}

Women farmers are making significant contribution to agriculture and food security (Gandahi, 2016: Buehren, Goldstein, Molina, \& Vaillan 2019). They are involved in all aspect of farming activities necessary for food production (Okwu, \& Umoru, 2018). Moreover, they participate in various agricultural activities ranging from crop production practices, livestock management and production practices, techniques of horticulture, post-harvest operations activities, fruit and vegetables production practices, agro forestry practices, and fish farming activities, as well as many other agricultural practices (Cisco \& Alungah, 2016; Gandahi, 2016). To achieve women progressive development socially and economically, there is need to study their participation in different areas human endeavour (Van Eerdewijk, Wong, Vaast, 
Creative Commons User License: CC BY-NC-ND

Abstracted by: EBSCOhost, Electronic Journals Service (EJS),

Google Scholar, Journal Seek, Scientific Commons,

Food and Agricultural Organization (FAO), CABI and Scopus
Journal of Agricultural Extension

Vol. 26 (1) January, 2022

ISSN(e): 24086851; ISSN(Print); 1119944X

http://journal.aesonnigeria.org

http://www.ajol.info/index.php/jae

Email: editorinchief@aesonnigeria.org

Newton, Tyszler, Pennington, 2017). This study determined women's participation in planning and implementation of agricultural practices

Rural Women Farmers (RWFs) undertake various agricultural and farming related practices (Gandahi, 2016). They contribute significantly toward agriculture (Ahmad \& Tanwir, 2016). The production rate among rural women comprised of about $33 \%$ of the total labour force (Kushwah, Dei, \& Kushwah, 2018). Despite women participation in agricultural activities and their effort toward food production which account for about 50 to 60 percent across the entire world (Savari, Shabanali, \& Daneshvar, 2015). Their ability to attain food security and self-sufficiency is underestimated especially in developing nations (Rani, Metha, \& Rani, 2019). Women farmers capability to achieve food security is not utilized (Aziz, Nisar, Koondhar, Meo, \& Rong, 2020; Abbasi et al., 2016). Their commitment toward food production is affected by lack of extension information (Food and Agricultural Organisation of United nation (FAO), 2017). In Nigeria women farmer are still poor and lack skills in planning and implementing modern farming practices due to lack of information and knowledge (Danye, 2018). Their participations in such activities mainly depend on their husband (Uduji \& OkoloObasi, 2018).

Agricultural extension services that ensure effective motivation and information delivery for women is essential for poverty reduction (Oluremi \& Gbenga, 2017; Olorunfemi, Olorunfemi, \& Oladele, 2020). It influences participation of farmer in agriculture (Kyaw et al., 2018) and enables them to make better economic decision (Drafor, 2016). Women farmers therefore need to be motivated to increase their knowledge, since lack of motivation reduce farmers participation (Nwafor et al., 2020) In Nigeria, organizations like the Agricultural Development Programme (ADP) seeks to increase the performance of extension services, but the major challenges have to do with motivational incentives for both extension workers and their client toward meeting the organizational goals (Machiadikwe et, al, 2016). Motivational work of extension workers influences farmers participation in farming practices and is an important variable that contribute toward engagement and empowerment of farmers for excellent performance. The work of motivation is undertaken by an individual who is responsible for providing courage to farmers.

There is also a wide gap between the extension service and level of farmers participation in planning agricultural practices. Therefore, rural women farmers participation in planning and implementation of agricultural practices in north eastern Nigeria were investigated. Specifically, the study determined:

1. the level of rural women farmers participation in planning agricultural practices and

2. the level of rural women farmers participation in implementation of agricultural practices. 
Creative Commons User License: CC BY-NC-ND

Abstracted by: EBSCOhost, Electronic Journals Service (EJS),

Google Scholar, Journal Seek, Scientific Commons,

Food and Agricultural Organization (FAO), CABI and Scopus
Journal of Agricultural Extension

Vol. 26 (1) January, 2022

ISSN(e): 24086851; ISSN(Print); 1119944X

http://journal.aesonnigeria.org

http://www.ajol.info/index.php/jae

Email: editorinchief@aesonnigeria.org

\section{Methodology}

The area is made of up six states namely, Adamawa, Bauchi, Borno, Gombe, Taraba and Yobe State. The study area is located on latitude $10^{\circ} 00^{\prime}-11^{\circ} 00^{\prime} \mathrm{N}$ and longitude $11^{\circ} 00^{\prime}-12^{\circ} 00^{\prime} \mathrm{E}$. The target population of the study consisted of 6758 rural women farmers in 24 rural communities of north eastern Nigeria. Out of the population, 378 women farmers were selected using multistage sampling procedure. The first stage involved purposive selection of two local government areas from each of the six states of north eastern Nigeria. The selection was based on their status of being the most rural areas. In the second stage, two communities were selected from each of the local government area using simple random sampling. In the third stage, rural women farmers were selected from each community using proportionate sampling. This is to ensure that the selected sample size reflect the population of RWFs from each of the rural community

Data were collected from the sample of rural women farmers on their perception on motivational effort of extension workers as well as rural women farmers participation in planning and implementation of agricultural practices. The study used questionnaire which was validated and subjected to reliability test as an instrument for data collection. The reliability coefficient of 0.87 was obtained after a pilot study. Data collected were analysed using mean, standard deviation and correlation statistics. The decision rule on the levels of motivation, planning and implementation was determined using 3 categories of mean value (Low 1.00-2.33, Moderate 2.34-3.67, and High 3.685.00).

\section{Result and Discussion}

Level of Rural Women Farmers Participation in Planning Agricultural Practices Table 1 shows level of panning on the usage of farm resources $(\bar{x}=2.57, S D=1.18)$ and management of farm products for marketing $(\bar{x}=2.46, \mathrm{SD}=1.24)$. The analyses also indicate low level of planning on how to keep farm record $(\bar{x}=1.40, \mathrm{SD}=0.18)$.

\section{Table:1 Participation in planning of agricultural practices among women} farmers

\begin{tabular}{lrr}
\hline Agricultural Practices & Mean & Std. Dev \\
\hline Plan on how to carry out my farm activities & 2.24 & 1.06 \\
Plan on the kind of agricultural inputs to use & 2.21 & 1.18 \\
Plan on how to keep my farm record & 1.40 & 0.18 \\
Plan on where to sale my farm products & 2.44 & 0.19 \\
Plan on when to collect and repay agricultural loan & 2.26 & 1.21 \\
Plan on the type of farm products to be produced & 2.41 & 1.31 \\
Plan on how to control pest, disease and natural enemy & 2.33 & 0.72 \\
Plan on the usage of my farm resources & 2.57 & 1.18 \\
Plan on how and when to harvest my farm produce & 2.36 & 0.52 \\
Plan on how to manage my farm products for marketing & 2.46 & 1.24 \\
& $\mathbf{2 . 2 7}$ & $\mathbf{0 . 8 8}$ \\
\hline
\end{tabular}

Source: Field Survey 2021 
Creative Commons User License: CC BY-NC-ND

Abstracted by: EBSCOhost, Electronic Journals Service (EJS),

Google Scholar, Journal Seek, Scientific Commons,

Food and Agricultural Organization (FAO), CABI and Scopus
Journal of Agricultural Extension

Vol. 26 (1) January, 2022

ISSN(e): 24086851; ISSN(Print); 1119944X

http://journal.aesonnigeria.org

http://www.ajol.info/index.php/jae

Email: editorinchief@aesonnigeria.org

Meanwhile, Table 1 reveals the mean average of 2.27 and SD of 0.88 which means RWFs in study area has achieved low level of planning agricultural practices. This implies that there is lack of planning on how to carryout agricultural practices among RWFs, this resulted in to lower level of agricultural yield produce and high investment of time and energy in farm labour by women farmers as pointed out by Kushwah, Dei, \& Kushwah, (2018) that agriculture production among rural women comprised of only $33 \%$ of the total labour force.

\section{Level of Rural Women Farmers Participation in the Implementations of Agricultural Practices}

Table 2 reveals the higher level of participation in divide the task of farm activities and implement accordingly $(\bar{x}=4.34, \mathrm{SD}=1.06)$, moderate participation in implementing all investment on farm $(\bar{x}=3.63, \mathrm{SD}=1.02)$ and in implementing strategies on how to improve farming activities $(\bar{x}=3.61, S D=0.98)$. Based on these findings, the mean average of 3.74 and SD of 1.27 the study indicates that there is high level of RWFs participation in implementation of agricultural practice in north eastern Nigeria, with the mean average of 3.74 and SD of 1.27 .

\section{Table 2: Participation in the implementation of agricultural practices}

\begin{tabular}{lcc}
\hline Implementation of activities & Mean & \multicolumn{2}{c}{$\begin{array}{l}\text { Std. } \\
\text { Dev }\end{array}$} \\
\hline Divide the task of farm activities and implement it & 4.34 & 1.06 \\
accordingly & 3.61 & 0.98 \\
Implement strategies on how to improve farming activities & 4.09 & 1.88 \\
Manage the farm products after harvest to avoid postharvest & & \\
losses & 3.44 & 1.19 \\
Purchase certain number of agricultural inputs for the farm & 3.46 & 1.31 \\
Manage the farm activities according to weather and season & 3.61 & 1.61 \\
Fully engaged in the control of my farm resources & 3.63 & 1.02 \\
Sincerely implement all investment on the farm & 3.77 & 1.18 \\
Participate in marketing of the farm produce & 3.46 & 1.22 \\
Participate in land preparation and management & 3.96 & 1.24 \\
Implement decision on farming system to be adopted & $\mathbf{3 . 7 4}$ & $\mathbf{1 . 2 7}$ \\
\hline
\end{tabular}

\section{Source: Field Survey 2021}

This is in line with the findings of Gandahi, (2016) that, rural women undertake various agricultural and farming related practices. Similarly, studies have shown women participate in all agricultural related activities ranging from crop production and animal husbandry (Rani, et. al, 2019).

\section{Conclusion and Recommendations}

Despite the higher level of rural women farmers participation in implementation of agricultural practices, there is still low level of planning agricultural practices among women farmers in rural areas. 
Creative Commons User License: CC BY-NC-ND

Abstracted by: EBSCOhost, Electronic Journals Service (EJS), Google Scholar, Journal Seek, Scientific Commons,

Food and Agricultural Organization (FAO), CABI and Scopus
Journal of Agricultural Extension

Vol. 26 (1) January, 2022

ISSN(e): 24086851; ISSN(Print); 1119944X

http://journal.aesonnigeria.org

http://www.ajol.info/index.php/jae

Email: editorinchief@aesonnigeria.org

Sakeholders in agricultural extension services should develop strategies and redesign extension policy and programme that would enable rural women farmers plan and successfully implement their farming activities. Similarly, extension programme for rural women farmers should consider their need, status and environment. This is to ensure availability and access of extension information and services that would result in increased productivity among women farmers in rural areas.

\section{References}

Abbasi, N., Ghoochani, O. M., Ghanian, M., \& Kitterlin, M. (2016). Assessment of households' food insecurity through use of a USDA Questionnaire. Adv Plants Agric Res, 4(5), 1-8.

Ahmad, T. I. \& Tanwir, F. (2016). Factors affecting women participation in livestock management activities; A case of Panjab Pakistan, MPRA Manich personal RePE achive no. 93312 05, may 2019

Aziz, N., Nisar, Q. A., Koondhar, M. A., Meo, M. S., \& Rong, K. (2020). Analyzing the women's empowerment and food security nexus in rural areas of Azad Jammu \& Kashmir, Pakistan: Bygiving consideration to sense of land entitlement and infrastructural facilities. Land Use Policy, 94, 104529.

Buehren, N., Goldstein, M., Molina, E., \& Vaillant, J. (2019). The impact of strengthening agricultural extension service on women farmers. Evidence from Ethiopia. Agricultural Economics (United Kingdom), 50(4),407-419.

Cisco O.B. \& Alungah O.C. (2016) Factors affecting rural women's participation in agriculture for development in Gatundu South Sub-County, Kiambu County, Kenya. International Review of Social Sciences and Humanities. 2(2), 97-107.

Danye, A. O. (2018). Assessment of mass media performance in agricultural information dissemination to rural farmers in Girei Local Government Area of Adamawa state, Nigeria. International journal of agricultural extension and rural development, 6(5), 639-647.

Drafor, I. (2016). Access to information for farm-level decision-making. Journal of Agricultural and Food Information, 17(4), 230-245. https://doi.org/10.1080/10496505.2016.1213170

Food and Agricultural Organisation (FAO (2017). Strategic Work of FAO to Reduce Rural Poverty. Rome: Food and Agriculture Organisation of the United Nations.

Gandahi, R., (2016) Role of rural women in agriculture. Pakistan Observer, 8(1), 5.

Kushwah, S., Dei, S, \& Kushwah, S (2018) Feminization of Indian agriculture, Key of doubling the agricultural income, International journal of current micro biology and applied science 1(7) 4941-4945

Kyaw, N. N., Ahn, S., \& Lee, S. H. (2018). Analysis of the factors influencing market participation among smallholder rice farmers in Magway Region, Central Dry Zone of Myanmar. Sustainability (Switzerland), 10(12). https://doi.org/10.3390/su10124441 
Creative Commons User License: CC BY-NC-ND

Abstracted by: EBSCOhost, Electronic Journals Service (EJS), Google Scholar, Journal Seek, Scientific Commons,

Food and Agricultural Organization (FAO), CABI and Scopus
Journal of Agricultural Extension

Vol. 26 (1) January, 2022

ISSN(e): 24086851; ISSN(Print); 1119944X

http://journal.aesonnigeria.org

http://www.ajol.info/index.php/jae

Email: editorinchief@aesonnigeria.org

Machiadikwe, N. Benjamin, A.N., \& Nnenna V. (2016). Level of extension agents' motivation and effectiveness in Abia State, Nigeria. International Journal of Scientific \& Technology Research 5 (4), 212-215.

Nwafor, C. U., Ogundeji, A. A. \& van der Westhuizen, C. (2020). Adoption of ICT-based information sources and market participation among smallholder livestock farmers in South Africa. Agriculture (Switzerland), 10(2). https://doi.org/10.3390/agriculture10020044

Okwu, O. J. \& Umoru, B. I. (2018). A Study of women farmers agricultural information needs and accessibility. A case study of Apa local government area of Imo state, Nigeria. African journal of Research \$(12), 1404- 1409

Oluremi, A. \& Gbenga, A. M (2017). Environmental factors affecting entrepreneurship development in Nigeria. Journal of sustainable development in Africa 13(40166- 176

Olorunfemi, T.O., Olorunfemi, O.D.\& Oladele O.I (2020) Determinants of the involvement of extension agents in disseminating climate smart agricultural initiatives: Implication for scaling up Journal of the Saudi Society of Agricultural Sciences 19(1), 285-292.

Rani, M., Metha, M. \& Rani, K (2019) Role of rural women in agriculture: A review. The Pharma Innovation Journal, 1 (5), 205-207.

Savari, S., Shabanali F. H., \& Daneshvar A. Z. (2015). Rural women's empowerment improving Household Food Security in the Divandarreh County. Journal of Research and Rural Planning, 3(8), 107-121

Uduji, J. I., Okolo-Obasi, E. N., \& Asongu, S. A. (2019). Corporate social responsibility and the role of rural women in sustainable agricultural development in sub-Saharan Africa: Evidence from the Niger Delta in Nigeria. Sustainable Development, 27(4), 692-703. https://doi.org/10.1002/sd.1933.

Van Eerdewijk, A.H.J.M., Wong, F., Vaast, C,. Newton, J., Tyszler, M., Pennington, A. (2017). White Paper: a Conceptual Model on Women and Girls 'Empowerment. Amsterdam: Royal Tropical Institute (KIT) p 82 